\title{
INTERRELASI BUDAYA PESERTA DIDIK DALAM PEMBELAJARAN IPS UNTUK MEWUJUDKAN HARMONISASI SOSIAL (STUDI KASUS DI SMP NEGERI 2 BANJAR AGUNG, KABUPATEN TULANG BAWANG)
}

\author{
Yusinta Tia Rusdiana, S.Pd., M.Pd. \\ Pendidikan Sejarah FKIP Universitas Muhammadiyah Palembang \\ yusintat@yahoo.com
}

\begin{abstract}
Abstrak
Keanekaragaman budaya yang dimiliki peserta didik tidak jarang menimbulkan perselisihan atau cara pandang berbeda baik mengenai logat bicara, karakter sehingga memungkinkan terjadinya interrelasi budaya peserta didik dalam proses pembelajaran sehingga terwujudnya harmonisasi sosial. Dalam Penelitian ini penulis menggunakan metode kualitatif deskriptif. Penelitian ini menunjukkan bahwa (1) Dalam menyusun perencanaan pembelajaran, guru membuat perangkat pembelajaran dengan mengkopi dari tim MGMP, (2) Pelaksanaan pembelajaran IPS di kelas yang memiliki keanekaragaman sudah terpadu tetapi guru tidak memanfaatkan hal tersebut dengan membentuk kelas multicultural, (3) Bentuk interrelasi budaya peserta didik dalam pembelajaran IPS di kelas berupa komunikasi verbal (bahasa Indonesia), pesan verbal (kata-kata, intonasi), komunikasi non verbal selama proses pembelajaran berupa keantusiasan peserta didik melalui bahasa tubuh (body language). (4) Kendala yang dihadapi guru di kelas yang memiliki keanekaragaman adalah guru kurang paham karakteristik peserta didik, sehingga peserta didik kurang termotivasi. Sedangkan kendala yang dihadapi peserta didik di lingkungan sekolah adalah adanya stereotip dan etnosentrisme peserta didik.
\end{abstract}

Kata Kunci: Interrelasi budaya, Pembelajaran IPS, Harmonisasi Sosial, SMP Negeri 2 Banjar Agung.

\begin{abstract}
Owned cultural diversity of learners is not uncommon led to disputes or different perspectives both about the accent, the character that allows the interrelation of culture of learners in the learning process so that the realization of social harmony. In this study the authors used method Descriptive Qualitative. This research shows that (1) in planning learning, teachers make learning device with a copy of the team MGMP (2) the implementation of learning social studies in the class that has the diversity already integrated but teachers do not take advantage of it by forming a class multicultural (3) form of interrelation of culture learners in learning social studies class in the form of verbal communication (Indonesian), verbal messages (words, intonation), non-verbal communication such as gestures during the learning process of students showed enthusiasm and body language. (4) the constraints faced by the class teacher is a teacher who has a diversity not understand the characteristics of students, so that students are less motivated. While the constraints faced by learners within the school are the stereotypes and etncentrism learners.
\end{abstract}

Keywords: Cultural Interrelations, Social Learning, Social Harmony, Junior High School 2 Banjar Agung

PENDAHULUAN

Pendidikan bertujuan untuk membentuk nilai budaya yang menyangkut cara berfikir bebas, tanpa ada tekanan atau paksaan dari berbagai pihak dan kreatif untuk menghasilkan gagasangagasan baru dalam mendekati suatu realitas, inovatif dalam mencari solusi permasalahan. Bangsa Indonesia adalah bangsa yang majemuk yang sarat dengan keberagaman, baik dalam ranah etnik, budaya, agama, maupun suku. Maka keberagaman ini harus dikelola dengan edukatif, sistematis, dan kreatif, agar menjadi aset bangsa yang tak ternilai. Kemajemukan yang ada pada bangsa Indonesia, disatu pihak bila disikapi secara 
arif dan bijaksana merupakan modal dasar sumber daya manusia. Bentuk interaksi yang terjadi dapat berupa kontak sosial maupun komunikasi.

Interrelasi budaya peserta didik didalam sebuah pembelajaran di kelas umumnya berupa komunikasi. Bentuk komunikasi dapat berupa pembicaraan, body language, gesture dan sikap. Interaksi sosial dalam masyarakat majemuk sering diwarnai dengan stereotip etnik, yaitu pandangan (image) umum suatu kelompok etnis terhadap kelompok etnis lain. Cara pandang stereotip diterapkan tanpa pandang bulu terhadap semua anggota kelompok etnis yang distereotipkan, tanpa memperhatikan adanya perbedaan yang bersifat induvidual. Budaya memberikan identitas kelompok orang, diantaranya dapat diidentifikasikan dari komunikasi dan bahasa. Sistem komunikasi verbal dan non verbal untuk membedakan kelompok satu dengan kelompok lainnya (Mulyana, 2001: 58).

Poortinga menganalisis mengenai hubungan yang terjalin antara etnis Lampung, Jawa, Batak dan Sunda. Etnis Jawa dan Sunda merasa bahwa diri mereka halus dan sopan sedangkan etnis Lampung dan Batak mempunyai sifat kasar, tegas, suaranya keras dan berisik, mudah marah serta suka bertengkar. Orang Batak memandang diri mereka sendiri sebagai berani, terbuka dan langsung, cerdas, rajin, kuat dan tangguh. Mereka menganggap hubungan etnis Jawa dan
Sunda sangat sopan dan halus, namun mereka penakut, lemah, dan ragu-ragu dalam berbicara (Liliweri, 2001: 176).

Peserta didik SMP Negeri 2 Banjar Agung, terdiri dari berbagai macam suku yang beragam seperti: suku Lampung, Jawa, Batak, Padang, Palembang dan Bali. Sehingga memungkinkan terjadinya interrelasi budaya peserta didik dalam pembelajaran IPS dan terjalin juga di lingkungan sekolah. Interelasi budaya adalah gabungan antara dua orang atau lebih yang memiliki kultur sebagai syarat penting bagi kehidupan masyarakat.

Interaksi simbolik mempelajari sifat interaksi yang merupakan kegiatan sosial dinamis manusia. Bagi perspektif ini, individu itu bukanlah sesorang yang bersifat pasif, yang keseluruhan perilakunya ditentukan oleh kekuatankekuatan atau struktur-struktur lain yang ada di luar dirinya, melainkan bersifat aktif, reflektif dan kreatif, menampilkan perilaku yang rumit dan sulit diramalkan. Karena individu akan terus berubah, maka masyarakat pun akan berubah melalui interaksi itu. Struktur itu tercipta dan berubah karena interaksi manusia, yakni ketika individu-individu berpikir dan bertindak secara stabil terhadap seperangkat objek yang sama (Mulyana, 2001: 59). Teori ini berpandangan bahwa kenyataan sosial didasarkan kepada definisi dan penilaian subjektif individu. Struktur sosial merupakan definisi bersama yang dimiliki individu yang berhubungan dengan bentuk-bentuk yang 
cocok, yang menghubungkannya satu sama lain. Tindakan-tindakan individu dan juga pola interaksinya dibimbing oleh definisi bersama yang sedemikian itu dan dikonstruksikan melalui proses interaksi.

Permasalahan dalam penelitian ini dirumuskan sebagai berikut:

Bagaimana perencanaan, pelaksanaan, interrelasi budaya, dan kendala yang dihadapi dalam pembelajaran IPS di kelas yang memiliki keanekaragaman budaya. Dalam pembelajaran IPS terdapat faktor penting sebagai penunjang keberhasilan pembelajaran. Salah satu faktor yang penting diantaranya adalah guru.

Keberhasilan seorang guru tampak dari pembelajaran yang dibuat, bahan ajar, metode/teknik, media dan evaluasi yang digunakan. Dewasa ini guru IPS hanya terfokus pada hafalan, padahal pembelajaran IPS hakikatnya adalah pembelajaran interrelasi aspek-aspek kehidupan manusia di masyarakat yang memadukan berbagai pengetahuan sosial. Berkaca dari hasil di atas, seorang guru perlu memahami cara peserta didik berkomunikasi hingga cara mereka berperilaku. Hal tersebut dapat mendukung keberhasilan peserta didik didalam pembelajaran IPS di kelas yang memiliki keanekaragaman budaya yang heterogen.

Kondisi kelas yang terdiri dari berbagai macam suku yang dimiliki peserta didik dan lingkungan sekolah seperti SMP N 2 Banjar Agung, diperlukan suatu upaya seorang guru untuk membangun suasana yang hangat untuk tercapainya komunikasi dan interaksi yang efektif antara guru dan peserta didik. Semua peserta didik baik laki-laki dan perempuan memiliki hak yang sama di dalam proses pembelajaran. Sehingga terciptanya harmoni sosial dan toleransi antar peserta didik. Begitu juga di lingkungan sekolah peserta didik yang memiliki keanekaragaman budaya harus saling menghormati dan menghargai satu sama lain. Tidak boleh ada yang menganggap suku/budayanya sendiri lebih unggul/baik.

Menurut Gagne dan Bringgs dalam Majid (2011:27) rencana pembelajaran yang baik hendaknya mengandung tiga komponen yang disebut anchor point yaitu 1) tujuan pengajaran, 2) materi pelajaran/bahan ajar, pendekatan dan metode mengajar, media pengajaran dan pengalaman belajar dan 3) evaluasi keberhasilan.

Jeanne Ellis Ormrod (2008:55) mengemukakan bahwa terdapat lima cara guru untuk membentuk sebuah kelas multikultural yaitu: 1) bekali diri anda dengan pengetahuan tentang budaya tempat siswa dibesarkan; 2) ambillah manfaat dari latar belakang budaya siswa; 3) gunakan materi kurikulum yang mewakili seluruh kelompok etnis secara positif dan kompeten, 4) kenalkan siswa pada tokoh-tokoh panutan yang sukses dari beragam latar belakang, 5) beri kesempatan siswa yang berasal dari latar belakang berbeda untuk saling mengenal dengan lebih baik. 
Blum (2001:229) mengemukakan bahwa Elemen-elemen pendidikan keanekaragaman, mencakup tiga sub-nilai sebagai berikut: pertama menegaskan identitas kultural seseorang, mempelajari dan menilai warisan budaya seseorang. kedua, menghormati dan berkeinginan untuk memahami serta belajar tentang etnik/kebudayaan-kebudayaan selain kebudayaannya. ketiga, menilai dan merasa senang dengan perbedaan kebudayaan itu sendiri yaitu memandang keberadaan dari kelompok-kelompok budaya yang berbedadalam masyarakat seseorang sebaikan kebaikan yang positif untuk dihargai dan dipelihara.

\section{METODE PENELITIAN}

Penelitian ini mendeskripsikan secara terperinci dan mendalam tentang Interrelasi budaya peserta didik dalam pembelajaran IPS, penelitian ini mengunakan metode Kualitatif-Deskriptif. Jenis penelitian ini mampu mengangkat berbagai informasi kualitatif secara lengkap dan mendalam untuk menjelaskan mengenai proses mengapa dan bagaimana sesuatu terjadi (Sutopo, 2006: 139). Strategi yang digunakan adalah studi kasus tunggal terpancang, studi kasus tunggal karena meneliti satu kasus yaitu Interrelasi Budaya Peserta Didik Dalam Pembelajaran IPS. Terpancang karena masalah sudah ditetapkan sebelum peneliti terjun ke lapangan.

Sumber data yang akan digali dalam penelitian ini meliputi Informan (kepala sekolah, guru IPS, dan peserta didik yang memiliki keanekaragaman budaya), Arsip dan dokumen, meliputi perangkat pembelajaran yaitu: program tahunan, program semester, RPP, silabus, portofolio peserta didik, inventaris sarana fisik dan jumlah peserta didik serta kegiatan proses pembelajaran IPS di kelas dan aktivitas peserta didik di lingkungan sekolah.

Teknik pengumpulan data menggunakan teknik wawancara mendalam, observasi langsung, analisis dokumen dan focus group discussion (FGD). Dalam penelitian ini digunakan triangulasi untuk mendapatkan data yang sahih. Validitas data menggunakan Teknik triangulasi yang digunakan adalah triangulasi sumber, peneliti, metode dan teori (Lexy Moloeng, 2008: 330). Teknik analisis data menggunakan analisis interaktif dengan tiga tahapan yang terjadi berkelindan yaitu reduksi data, sajian data, dan penarikan simpulan atau verifikasi (Miles \& Huberman, 1992: 16).

\section{HASIL DAN PEMBAHASAN}

Perencanaan yang dilakukan guru IPS di SMP Negeri 2 Banjar Agung, guru IPS sudah melengkapi administrasi pembelajaran seperti membuat Silabus dan RPP. Di dalam rencana pelaksanaan pembelajaran yang telah dibuat guru terdapat langkah-langkah pembelajaran yang dimulai dari kegiatan pendahuluan, inti (eksplorasi, elaborasi dan konfirmasi), kegiatan penutup, sumber belajar dan 
penilaian. Sehingga rencana pelaksanaan pembelajaran (RPP) yang dibuat guru IPS nampak tidak berbeda seperti sekolah lain pada umumnya. Sedangkan berdasarkan temuan penelitian perencanaan pembelajaran IPS di kelas yang memiliki keanekaragaman guru IPS sudah melengkapi administrasi pembelajaran seperti membuat perangkat silabus dan RPP. Namun dalam membuatnya guru hanya mengkopi panduan tim musyawarah guru mata pelajaran (MGMP). Sehingga terlihat perencanaan pembelajaran hanya dibuat sekedarnya. Di dalam silabus dan RPP, materi dirancang untuk 3 kali tatap muka dengan alokasi keseluruhan 6x40 menit. Guru pada praktek pembelajarannya menggunakan beberapa metode pembelajaran, yakni ceramah bervariasi, diskusi, tanya jawab, inquiri. Dalam tahap perencanaan guru menyusun stantar kompetensi (SK) masih secara terpisah mata pelajaran terdiri: geografi, sejarah, ekonomi dan sosiologi. Dengan adanya rencana pembelajaran maka mendorong pencapaian objektivitas dan tujuan pembelajaran, pemilihan materi pembelajaran, perencanaan proses belajar mengajar, penggunaan media belajar mengajar dan evaluasi.

Pelaksanaan pembelajaran di kelas dimulai guru dengan mengucapkan salam, berdoa bersama kemudian menyampaikan tujuan pembelajaran yang akan dicapai yang sesuai dengan topik yang akan dibahas. Pada tahap eksplorasi, guru IPS menjelaskan materi misalnya "Kondisi
Fisik Wilayah Indonesia", guru IPS tidak hanya menjelaskan dari sudut pandang mata pelajaran geografi tetapi guru mengkaitkan antara materi satu dengan lainnya kemudian dikemas secara menarik dan mudah dipahami oleh peserta didik. Pada tahap penutup guru menyimpulkan materi yang telah dijelaskan, dan memberi penekanan pada materi yang dianggap penting. Diakhir pembelajaran guru akan memberi tugas kepada peserta didik. Pelaksanaan pembelajaran di SMP Negeri 2 Banjar Agung pembelajaran IPS tidak sesuai dengan RPP yang dibuat oleh guru, dalam pembuatannya masih terpisah-pisah (georafi, sejarah, ekonomi, sosiologi). Dalam proses pembelajaran di kelas materi disampaikan oleh guru secara terpadu. Hal ini tentu tidak sesuai dengan perencanaan yang telah disusun sebelum melaksanakan pembelajaran. Selain itu, guru hanya menjelaskan materi persis seperti tertulis dalam buku teks tanpa adanya upaya melakukan improvisasi yang dapat membangkitkan minat dan motivasi peserta didik.

Pelaksanaaan pembelajaran IPS di kelas yang memiliki keanekaragaman masih belum memenuhi syarat pembelajaran IPS yang baik. Hal ini dikarenakan guru IPS hanya mengunakan metode ceramah dan hanya kadangkadang menggunakan metode diskusi. SMP Negeri 2 Banjar Agung, peserta didik di kelas terdiri dari berbagai macam suku seperti Jawa, Padang, Lampung, Sunda, Batak dan Bali. Dengan adanya 
keanekaragaman guru dapat mengunakan metode kooperatif yang mampu merangsang peserta didik yang heterogen untuk aktif dan kreatif dalam menggembangkan ide atau pendapat. Dengan adanya hal demikian terdapat keuntungan tersendiri bagi sebuah sekolah yang memiliki keanekaragaman budaya. Hal tersebut dapat dimanfaatkan dalam pembelajaran dengan membentuk kelas multikultural.

Interrelasi budaya peserta didik dalam pembelajaran IPS berupa komunikasi verbal (bahasa), komunikasi non verbal, dan body language. Pelaksanaan pembelajaran di kelas saat guru membagi diskusi kelompok berdasarkan kelompok ahli atau absen peserta didik. Disinilah komunikasi verbal menunjukkan peserta didik kurang dapat bekerjasama dengan suku lain. Idealnya suatu kegiatan komunikasi dapat berjalan dengan baik dan mencapai tujuan yang diharapkan jika antara orang yang terlibat dalam komunikasi tersebut mempunyai persamaan latar belakang. Orang Jawa akan lebih mudah berkomunikasi dengan orang jawa pula, dari pada ia berkomunikasi dengan orang Batak, Sunda atau suku-suku lain di luar suku Jawa.

Ketika diskusi kelompok berjalan peserta didik suku Batak menunjukkan keantusiannya saat mempresentasikan hasil diskusi kelompok dengan ekspresi wajah senang. Sedangkan peserta didik suku Bali memperlihatkan pesan verbal ekspresi wajah nampak cemberut menunjukkan sedang binggung dan kesal. Peserta didik mengunakan anggukan kepala ketika peserta didik setuju akan pendapat suku lain dalam menyampaikan pendapatnya. Sedangkan body languge ditunjukkan peserta didik suku Jawa saat guru menjelaskan materi menunjukkan sikap duduk siap tangan diatas meja pandangan fokus kedepan memperhatikan penjelasan guru.

Interrelasi budaya peserta didik dilingkungan yang memiliki keanekaragaman bahasa daerah asli/pribumi memang tidak dapat dipisahkan terutama bertemu dengan seseorang yang memiliki latar budaya yang sama. Seseorang cenderung mengunakan bahasa daerahnya sebagai identitas budayanya ketika berelasi dengan teman yang sama daerahnya. Sedangkan suku lain berusaha memahami bahasa daerah asli/Lampung dengan mengikuti mata pelajaran muatan lokal yang terdapat di sekolah.

Interrelasi budaya peserta didik terjalin dengan baik melalui kegiatan ektrakulikuler di sekolah. Terdapat ekskul yang dapat diikuti diantaranya: Pramuka, Rohis, Basket, Bola Volly, Futsal, Seni Tari dan Vokal. Melalui saluran ini peserta didik mampu menggembangkan skill sesuai dengan bakat dan minat yang dimiliki sedangkan di luar kelas mereka berkumpul di kantin untuk berbincang-bincang.

Kendala yang dihadapi di kelas yang memiliki keanekaragaman adalah kendala tersebut berasal dari internal 
(guru). Kemampuan penting yang harus dimiliki oleh seorang guru adalah seseorang guru harus memiliki pengetahuan yang luas, sikap \& kepribadian yang baik dan berkemampuan berkomunikasi sosial. Selain itu hambatan tidak hanya berasal dari faktor pendidik, tetapi berasal dari faktor orang tua peserta didik. Kurangnya peran orang tua dalam mendidik anak akan mengakibatkan penurunan sikap anak. Hal ini akan berdampak ketika mengikuti pelajaran keesokan harinya.

Sedangkan kendala yang dihadapi peserta didik di lingkungan sekolah yang memiliki keanekaragaman adalah kedudukan suku Lampung masih mendapatkan kedudukan yang unggul dibanding suku lain. Kendala selanjutnya yang dihadapi peserta didik di lingkungan sekolah adanya stereotip dan etnosentrisme. Kesulitan komunikasi akan muncul dari penstereotipan yakni menggeneralisasikan orang-orang berdasarkan sedikit informasi dan membentuk asumsi orang-orang berdasarkan keanggotaan mereka dalam suatu kelompok. Dengan kata lain, penstereotipan adalah proses menempatkan orang-orang kedalam kategori-kategori yang mapan, atau penilaian mengenai orang-orang atau objek berdasarkan kategori-kategori yang sesuai, ketimbang berdasarkan karakteristik induvidual mereka. Stereotip dapat membuat informasi yang kita terima tidak akurat. Pada umumnya, stereotip bersifat negatif. Stereotip tidak berbahaya sejauh kita simpan dikepala kita, namun akan bahaya bila diaktifkan dalam hubungan manusia. Stereotip dapat menghambat atau mengganggu komunikasi itu sendiri. Misalnya kita melakukan persepsi stereotip terhadap orang Padang itu pelit. Etnosentrisme adalah memandang sesuatu dalam kelompok sendiri sebagai pusat segala sesuatu itu, dan hal-hal lainnya dinilai berdasarkan rujukan kelompoknya.

\section{PENUTUP}

\section{Simpulan}

Berdasarkan hasil penelitian dan pembahasan yang telah dikemukakan pada bab-bab sebelumya maka disimpulkan sebagai berikut:

1. Perencanaan pembelajaran yang dilakukan guru IPS sudah melengkapi administrasi pembelajaran dengan membuat silabus dan RPP. Namun perencanaan yang dibuat oleh guru tidak berbeda dengan sekolah lain dalam pembuatannya guru hanya mengkopi paste dari tim musyawarah guru mata pelajaran (MGMP). Di dalam RPP yang dibuat guru standar kompetensi masih terpisah-pisah antara mata pelajaran geografi, ekonomi, sejarah, sosiologi.

2. Pelaksanaan pembelajaran di kelas dilakukan dengan tiga tahap yaitu tahap elaborasi, eksplorasi dan konfirmasi. Dalam menyampaikan materi guru sudah mengkaitkan 
pelajaran secara terpadu, hal tersebut tidak sesuai dengan RPP yang dibuat, standar kompetensi masih terpisahpisah sehingga pembelajaran di kelas cenderung tidak sistematis sesuai perencanaan yang seharusnya dilaksanakan. Dalam pelaksanaan guru masih mengunakan metode konvensional, seharusnya peserta didik yang beranekaragam budaya guru mengunakan metode pembelajaran kooperatif yang mampu merangsang peserta didik yang heterogen untuk aktif dan kreatif dalam menggembangkan ide atau pendapat.

3. Interrelasi budaya peserta didik dalam pembelajaran IPS berupa komunikasi verbal (bahasa Indonesia), komunikasi non verbal, dan body language. Interrelasi budaya peserta didik di lingkungan yang memiliki keanekaragaman bahasa daerah asli/pribumi memang tidak dapat dipisahkan terutama bertemu dengan seseorang yang memiliki latar budaya yang sama khususnya peserta didik suku Lampung. Interrelasi budaya peserta didik terjalin erat melalui kegiatan ektrakulikuler di sekolah dan ketika berada di luar kelas jam istirahat mereka berkumpul di kantin untuk berbincang-bincang.

4. Kendala yang dihadapi di kelas yang memiliki keanekaragaman adalah tidak hanya faktor internal (guru), tetapi juga berasal dari faktor orang tua peserta didik. Sedangkan kendala yang dihadapi peserta didik saat berada di lingkungan sekolah adalah peserta didik pribumi merasa masih berpegang teguh kepada nilai-nilai sosial masyarakat Lampung, sehingga menyebabkan peserta didik tidak mau membaur dan hanya mengelompok saja, serta adanya pandangan sikap stereotip dan etnosentrisme yang dimiliki peserta didik.

\section{Saran}

Kepada Kepala Sekolah: (a) mendukung pembentukan kelas multikultural di SMP Negeri 2 Banjar Agung, (b) Kepala Sekolah dan guru dapat menjalin komunikasi lebih intensif kepada orang tua peserta didik untuk memecahkan berbagai masalah yang dihadapi. Kepada guru IPS: (a) dapat menambah penggunaan metode dan strategi pembelajaran yang lebih inovatif dan kreatif, (b) guru hendaknya menggembangkan keanekaragaman peserta didik dengan membentuk kelas multikultural, dengan adanya pendidikan multikultural memberikan kesempatan baik putra maupun putri yang memiliki kultur berbeda akan mendapatkan kesempatan yang sama untuk mencapai prestasi akademis di sekolah.

\section{DAFTAR PUSTAKA}

Blum, A. Lawrence. 2001. Antirasisme, Multikulturalisme, dan Komunitas Antar Ras, Tiga Nilai yang Bersifat Mendidk Bagi Sebuah Masyarakat Multikultural, dalam Larry May, dan Shari Colins-Chobanian, Etika Terapan: Sebuah Pendekatan 
Multikultura, Terjemahan: Sinta Carolina dan Dadang Rusbiantoro, Yogyakarta: Tiara Wacana.

Liliweri, Alo. 2001. Dasar-Dasar Komunikasi Antar Budaya. Pustaka Pelajar: Yogyakarta.

........... 2005. Prasangka dan Konflik

Komunikasi Lintas Budaya

Masyarakarat Multikultural. LKIS: Yogyakarta.

1991. Komunikasi Antar Pribadi. Bandung: Citra Aditya Bakti.

Majid, A. 2011. Perencanaan Pembelajaran. Bandung: PT. Remaja Rosdakarya.

Miles B. Matthew dan Huberman A. Michael. 1992. Analisis Data Kualitatif: Buku Sumber tentang Metode-metode Baru. terjemahan: Tjetjep Rohendi Rohidi. Jakarta: UI Press.

Mulyana, Deddy. 2001. Komunikasi Antarbudaya: Panduan Berkomunikasi dengan orang-orang berbeda budaya. Bandung: Rosdakarya.

Ormrod, J.E. (2003). Educational psychology, Developing learners. Fourth Edition. New Jersey: Pearson Education, Inc.

Sutopo, H.B. 2006. Metodologi Penelitian Kualitatif. Surakarta: Jurusan Seni Rupa Fakultas Sastra UNS. 